\title{
A bird and small mammal BACI and IG design studies in a wind farm in Malpica (Spain)
}

\author{
MANUELA DE LUCAS*, GUYONNE F.E. JANSS and \\ MIGUEL FERRER

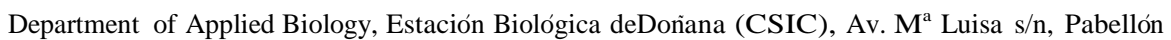 \\ de Perú, 41013 Seville, Spain; *Author for correspondence (e-mail: manuela@ebd.csic.es; phone: \\ 34-954-23-23-40; fax: 34-954-62-11-25)
}

Key words: BACI design, Birds, IG design, Small mammals, Wind farm

\begin{abstract}
Wind farms have shown a spectacular growth during the last 10 years. As far as we know, this study is the first where the relationship between wind power and birds and small mammals have been considered. Before-after control impact (BACI) study design to birds and Impact Gradient (IG) study design to small mammals to test the null hypothesis of no impact of a wind farm were used. In the BACI model Windfarm Area and a Reference Area were considered. Distance from turbines was considered in the IG model. Windfarm installations did not clearly affect bird and small mammal populations. Flight height of nesting and no nesting birds did not show a clear tendency. Small mammals populations suffered high variations in numbers through times by intrinsic population factors. There are many practical problems of detection of human influence on abundances of populations so sampling in the long run can be suggested.
\end{abstract}

\section{Introduction}

Wind farms are a relatively new form to obtain 'clean' energy by avoiding air pollution and other forms of environmental degradation associated with fossil fuel technologies (Nelson and Curry 1995) and have received strong public support as an alternative energy source (Leddy et al. 1999). Moreover, wind farms have shown a spectacular growth because they have reduced the costs of energy production and produced a clean energy. This phenomenon has generated a proliferation of wind farms around the world (Germany, Spain, United States, etc) (Osborn et al. 2000).

Most of studies about possible effects of wind power on wildlife animals have been focused on birds, specifically on avian activity, habitat use and bird mortality (Winkelman 1990; Orloff and Flannery 1992; Musters et al. 1996; Howell 1997; Dirksen et al. 1998; Morrison and Sinclair 1998; Strickland et al. 1998; Thelander and Rugge 1998; Osborn et al. 2000; Erickson et al. 2001; de Lucas et al. 2004). None have studied the effects of wind power on small mammal communities.

The Before-after control impact (BACI) design has been called the 'optimal impact study design' (Anderson et al. 1999). The aim of BACI studies is to compare environmental variables before and after a human activity (e.g. the 
construction of the windfarm) and between the area presumably affected by the development and a control area (Stewart-Oaten 1986; Guillemette et al. 1998). Use of reference areas increases the reliability of conclusions concerning quantification of impact (Underwood 1994).

We used bird abundance to assess the impact of a construction of a wind farm. Changes in the abundance of organisms is a good impact indicator, but abundance vary naturally through time, so any change observed in an assessment area between the pre- and post-impact periods could conceivably be unrelated to the treatment. In the analysis of impact the percentage of biological indicators that are significantly different (positive and negative) when tested at a given level of significance (Page et al. 1993; Stekoll et al. 1993) is used to determine the direction and magnitude of the impact. In this study rodents were also studied using an Impact-Gradient (IG) Design. This study design is used for impact quantification in relatively small assessment areas on homogeneous environments. The analysis was based on the relationship between the impact indicator and distance of rodent captures from the wind turbines.

We tested the null hypothesis of no effect of a wind farm on birds and small mammals in Malpica (A Coruna, Spain). We used a BACI design to analyse: (1) the possible impacts of the wind farm on nesting and no nesting bird communities, (2) flight behavioural of both nesting and no nesting birds resulting from the presence of a wind farm; and we used a IG design to analyse the possible impacts of the wind farm on rodents.

Study area

The study area was conducted in Malpica (A Coruna), in the northwestern Spain (Figure 1) from June 1995 to June 1997. In this part of Spain high density of migrating and shore birds can be observed. Here, the shore birds arrive when the weather is bad. This area was swept away by strongest winds from Atlantic storm (Natural 1995a, b; Alonso 2002).

In this area 73 breeding passerine and raptor species can be found (see Table 1 and 3). Only Montagu's Harriers was classified like vulnerable in Spain by the Red Book (Blanco and Gonzalez 1992) Colonies of breeding Yellowlegged Gulls Larus cachinnans were distributed along the coastline (Natural 1995a).

Small mammals community were composed by Western Hedgehog Erinaceus europaeus, Iberian Mole Talpa occidentalis, Common Shrew Sorex araneus, Pygmy Shrew S. minutus, Wood Mouse Apodemus sylvaticus, Miller's Water Shrew Neomys anomalus, Greater White-toothed Shrew Crocidura russula, and Lesser White-toothed Shrew C. suaveolens (Natural 1995b). Blanco and Gonzalez (1992) had classified Iberian Mole like insufficient acquaintance.

The study was carried out in the Malpica Windfarm. This windfarm was $150-200 \mathrm{~m}$ above sea level and $160-200 \mathrm{~m}$ far from the coast. The wind farm 
consisted of 67 wind turbines Ecotecnia 28/225. This model has a tubular steel tower of $32 \mathrm{~m}$ and its rotor is $20 \mathrm{~m}$ in diameter. Rotor was orientated windward, and have three blades. The total power of wind farm was $15 \mathrm{MW}$. The turbines strings were aligned in 7 rows and they were orientated from North-West to South-East. Within strings, wind turbines were separated between 60 and $90 \mathrm{~m}$. From now on, we will refer to this area as the WF Area (Windfarm).

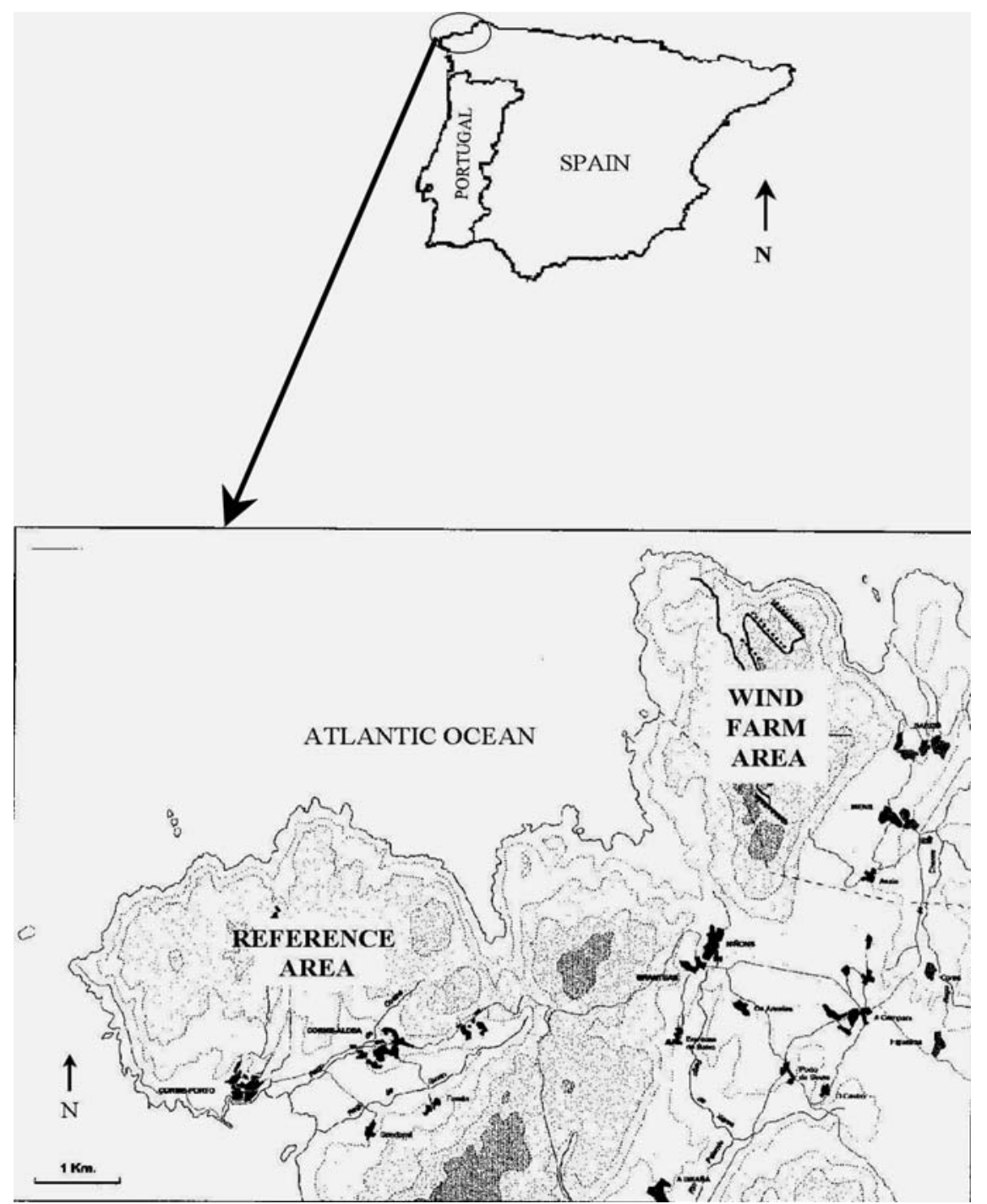

Figure 1. Map of the study areas in Malpica (Galicia Region, northwestern Spain). 
Table 1. Abundance (numbers of birds $/ \mathrm{km}$ ) of nesting bird species in the two study areas and in all study period.

\begin{tabular}{|c|c|c|c|c|c|c|}
\hline \multirow[t]{2}{*}{ Nesting species } & \multicolumn{3}{|c|}{ Wind farm area } & \multicolumn{3}{|c|}{ Reference area } \\
\hline & 1995 & 1996 & 1997 & 1995 & 1996 & 1997 \\
\hline Alauda arvensis (Skylark) & 1.54 & 1.46 & 1.99 & 0.34 & 0.19 & 0.00 \\
\hline Anthus trivialis (Tree pipit) & 0.00 & 0.31 & 0.13 & 0.05 & 0.22 & 0.13 \\
\hline Carduelis cannabina (Linnet) & 3.03 & 5.58 & 6.92 & 7.60 & 3.49 & 8.91 \\
\hline Carduelis carduelis (Goldfinch) & 1.32 & 0.81 & 1.41 & 0.87 & 1.96 & 0.83 \\
\hline Carduelis chloris (Greenfinch) & 0.81 & 1.31 & 1.35 & 0.77 & 0.83 & 0.51 \\
\hline Cisticola juncidis (Fan-tailed warbler) & 0.00 & 0.00 & 0.00 & 0.00 & 0.32 & 0.06 \\
\hline Emberiza cirlus (Cirl bunting) & 0.00 & 0.00 & 0.00 & 0.00 & 0.00 & 0.06 \\
\hline Erithacus rubecula (Robin) & 0.04 & 0.00 & 0.06 & 0.00 & 0.13 & 0.13 \\
\hline Fringilla coelebs (Chaffinch) & 0.04 & 0.00 & 0.00 & 0.00 & 0.00 & 0.00 \\
\hline Hyppolais polyglota (Melodious warbler) & 0.00 & 0.04 & 0.00 & 0.00 & 0.13 & 0.00 \\
\hline Lullula arborea (Woodlark) & 0.00 & 0.00 & 0.13 & 0.00 & 0.03 & 0.00 \\
\hline Muscicapa striata (Spotted flycatcher) & 0.21 & 0.00 & 0.00 & 0.05 & 0.00 & 0.00 \\
\hline Parus ater (Coal tit) & 0.00 & 0.23 & 0.00 & 0.29 & 0.26 & 0.06 \\
\hline Parus major (Great tit) & 0.00 & 0.00 & 0.06 & 0.00 & 0.00 & 0.26 \\
\hline Prunella modularis (Dunnock) & 0.47 & 0.58 & 2.12 & 0.77 & 1.28 & 1.99 \\
\hline Saxicola torquata (Stonechat) & 2.74 & 2.77 & 4.68 & 1.83 & 1.57 & 2.95 \\
\hline Sylvia atricapilla (Blackcap) & 0.00 & 0.00 & 0.00 & 0.00 & 0.00 & 0.13 \\
\hline Sylvia conspicillata (Spectacled warbler) & 0.00 & 0.00 & 0.00 & 0.00 & 0.35 & 0.06 \\
\hline Sylvia undata (Dartford warbler) & 0.00 & 1.96 & 2.63 & 2.12 & 0.64 & 1.03 \\
\hline Troglodytes troglodytes (Wren) & 0.34 & 0.73 & 1.35 & 0.29 & 0.22 & 0.64 \\
\hline Turdus merula (Blackbird) & 0.26 & 0.27 & 0.96 & 0.53 & 1.70 & 1.35 \\
\hline Total & 10.94 & 16.04 & 23.97 & 15.48 & 13.33 & 19.23 \\
\hline Birds $/ \mathrm{km}$ & $256 / 23.4$ & $417 / 26$ & $374 / 15.6$ & $322 / 20.8$ & $416 / 31.2$ & $300 / 15.6$ \\
\hline
\end{tabular}

Table 2. IKA index of nesting species between study areas and study periods were analysed with Wilcoxon Test.

\begin{tabular}{lllllll}
\hline Years & Areas & Mean & SD & n & Z & p \\
\hline 1995 (pre) & WF & 0.332 & 0.216 & 24 & 0.302 & 0.763 \\
\multirow{2}{*}{1996 (const) } & R & 0.349 & 0.168 & & & \\
& WF & 0.337 & 0.225 & 32 & -2.348 & 0.019 \\
1997 (post) & R & 0.462 & 0.131 & & & 0.243 \\
& WF & 0.375 & 0.502 & 36 & -1.168 & \\
\hline
\end{tabular}

A near area without turbines was included in this study to be used as a reference area. This area and WF Area were separated by $6 \mathrm{~km}$. The reference area was 100-150 m a.s.1. and 150-170 $\mathrm{m}$ far from the coast. From now on, we will refer to this area as the $\mathrm{R}$ Area (Reference).

The flora's species on both study areas were very similar, consisting in bush of Ulex sp. and small wood of Southern Blue-gum Eucaliptus globulus and Maritime pine Pinus pinaster (Rivas-Martınez 1987). Some area were cut by 
Table 3. Abundance (numbers of birds $/ \mathrm{km}$ ) of no nesting bird species in the two study areas and in all study period.

\begin{tabular}{|c|c|c|c|c|c|c|}
\hline \multirow[t]{2}{*}{ No nesting species } & \multicolumn{3}{|c|}{ Wind farm area } & \multicolumn{3}{|c|}{ Reference area } \\
\hline & 1995 & 1996 & 1997 & 1995 & 1996 & 1997 \\
\hline Apus apus (Swift) & 0.00 & 0.08 & 0.00 & 0.14 & 0.38 & 0.32 \\
\hline Buteo buteo (Buzzard) & 0.26 & 0.27 & 0.06 & 0.24 & 0.06 & 0.06 \\
\hline Columba palumbus (Woodpigeon) & 0.00 & 0.12 & 0.13 & 0.34 & 0.10 & 0.13 \\
\hline Corvus corax (Raven) & 0.04 & 0.00 & 0.00 & 0.00 & 0.00 & 0.00 \\
\hline Corvus corone corone (Carrion Crow) & 0.00 & 0.04 & 0.45 & 1.06 & 1.12 & 1.22 \\
\hline Corvus monedula (Jackdaw) & 0.00 & 0.00 & 0.00 & 0.05 & 0.00 & 0.00 \\
\hline Delichon urbica (House martin) & 0.00 & 0.04 & 0.00 & 0.00 & 0.00 & 0.00 \\
\hline $\begin{array}{l}\text { Dendrocopos major (Great spotted } \\
\text { woodpecker) }\end{array}$ & 0.09 & 0.04 & 0.00 & 0.00 & 0.06 & 0.06 \\
\hline Emberiza citrinella (Yellowhammer) & 0.30 & 0.00 & 0.00 & 0.00 & 0.00 & 0.00 \\
\hline Falco tinnunculus (Common kestrel) & 0.13 & 0.04 & 0.06 & 0.05 & 0.00 & 0.00 \\
\hline Hirundo rustica (Swallow) & 0.00 & 0.00 & 0.13 & 0.00 & 0.00 & 0.00 \\
\hline Larus cachinnans (Yellow-legged gull) & 2.52 & 2.54 & 0.77 & 7.16 & 2.85 & 1.99 \\
\hline Luscinia megarhynchos (Nightingale) & 0.00 & 0.00 & 0.00 & 0.05 & 0.00 & 0.00 \\
\hline Motacilla alba (Pied wagtail) & 0.00 & 0.00 & 0.00 & 0.05 & 0.00 & 0.00 \\
\hline Phoenicurus ochruros (Black redstart) & 0.00 & 0.00 & 0.13 & 0.00 & 0.00 & 0.00 \\
\hline Picus viridis (Green woodpecker) & 0.00 & 0.12 & 0.13 & 0.05 & 0.10 & 0.00 \\
\hline Streptopelia turtur (Turtle dove) & 0.00 & 0.08 & 0.00 & 0.10 & 0.77 & 0.83 \\
\hline Sturnus unicolor (Spotless starling) & 0.00 & 0.00 & 0.06 & 0.00 & 0.00 & 0.06 \\
\hline Total & 3.59 & 3.35 & 3.33 & 9.23 & 5.45 & 5.58 \\
\hline Birds/km & $84 / 23.4$ & $87 / 26$ & $52 / 15.6$ & $192 / 20.8$ & $170 / 31.2$ & $87 / 15.6$ \\
\hline
\end{tabular}

farmers, then grazing land and heather proliferated. Also, in R Area some fields were sowed with corn Zea mays and wheat Triticum sp.

\section{Methodology}

The study was carried out through three years (1995, 1996 and 1997), during the second fortnight of June. BACI and IG models were used for this study. Three periods were defined: pre-construction (June 1995), construction (June 1996) and post-construction (June 1997) of the wind farm.

We studied several variables concerning birds analysing for differences among study areas and study periods. Variables were recorded along fixed length transects in both areas. We also studied several variables concerning small mammals comparing study periods in WF Area only. Three groups of variables were recorded in this comparative study: (1) specific composition (number of species present), relative abundance (IKA: no. birds $/ \mathrm{km}$ ) and density (birds $/ \mathrm{km}^{2}$ ) of nesting and no nesting birds; (2) flight behavioural of nesting and no nesting birds (direction and flight height); and (3) specific composition (number of species present) and abundance of small mammals in WF Area. 
We distinguish between nesting birds and no nesting birds based in the following criteria: (1) nesting birds were all passerine birds (except corvids) which were in the study areas during reproductive period; (2) nesting birds were all those bird species whose breed in the study areas were known; and (3) nesting birds were all those bird species whose reproductive requirements were in the study areas.

Avian mortality was not studied because the windfarm had been operating as full potential only for a few months.

Composition, abundance and density of birds

The abundance, density and composition of bird's communities in both study areas were detected by transect method (Telleria 1986). In each study area, we selected a census' transect and recorded all visual contact with birds or flocks of birds walking to constant velocity. Both transects were circular and measured $2.6 \mathrm{~km}$ over the 3 year study (the second fortnight of June). A total of $32 \mathrm{~h}$ was dedicated to monitoring transects per year. In all cases, the census were executed at the first hours in the morning or at dusk.

When we observed a bird, several variables such as date, hour, species, number of birds, sex, age, climatic conditions (wind velocity and wind direction), habitat where birds were (rocks, bushes, trees and grazing land) and distance to transect were recorded. With this data, an index of avian abundance per $\mathrm{km}$ (IKA) and an avian density per $\mathrm{km}^{2}$ in each study area were calculated (Ferry and Frochot 1958).

Flight behaviour of birds

Flight behaviour was recorded by direct observation from linear-transects by foot in each area (as above). When we observed birds the same variables as those mentioned for avian abundance and composition were recorded. Anemometer towers located in the wind farm measured climatic conditions (wind velocity and wind direction). These data were used in $\mathrm{R}$ Area too due to the proximity of both areas and their similar morphology characteristics.

Flight behaviour was described by flight altitude, flight direction, kind of flight and singing (if bird was singing or not). Flight altitude and flight direction were calculated by direct observations.

\section{Composition and abundance of small mammals}

The specific composition was detected with 'capture - marked - recapture' model using live trap with bate (Orrock et al. 2000). The traps measured $28-10-7 \mathrm{~cm}$. Traps were checked twice at day: in the morning and in the 
afternoon, every 10 study days per study period. When a small mammal was captured, several variables such as species, sex and reproductive condition were recorded. The captured small mammals were marked by cutting a lock.

The relative abundance were detected with footprint searches on specific gadgets. Therefore we used PVC tubes with $29 \mathrm{~cm}$ long and $7 \mathrm{~cm}$ in diameter with a white paper with a mixture of charcoal and oil inside. The small mammal's footprints were imprinted in these white papers when passing through the oil mixture.

The traps and tubes were distributed alternated and separated by $20 \mathrm{~m}$ along 4 line transects covering WF Area (Figure 2). The same points were used in all the study period. They were classified in four categories: less than $40 \mathrm{~m}$ to the turbines, between 40 and $80 \mathrm{~m}$ to the turbines, between 80 and $120 \mathrm{~m}$ to the turbines and more than $120 \mathrm{~m}$ to the turbines. The line transects were placed from the North to the South. Also, to each point several variables about landscape were recorded such as kind of morphological features and vegetation (rocks, bushes, pines and grassland), vegetation cover (open, middle and dense) and homogeneity of landscape (uniform and edge).

An index of captures in each study year was calculated dividing the number of captured small mammals by study days and by number of active traps.

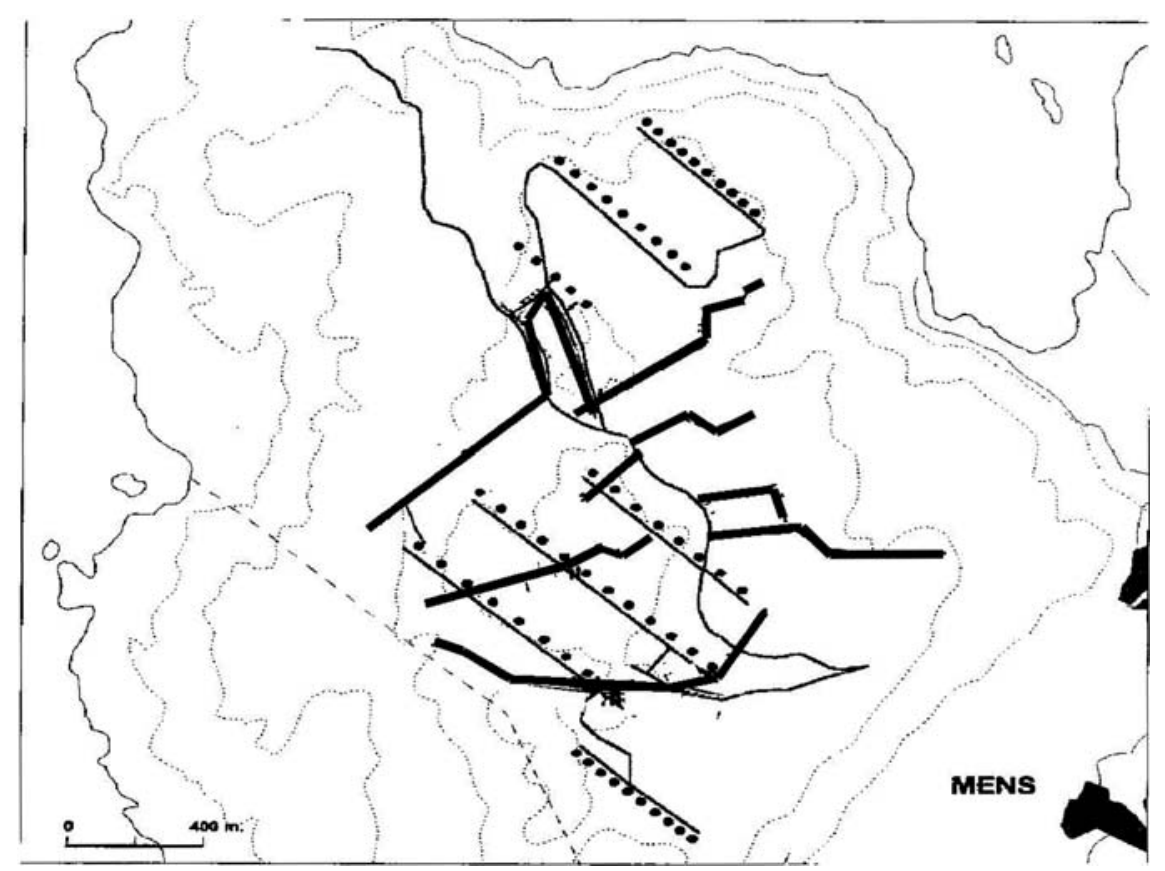

Figure 2. Map of the transects (dark lines) used to distributed all traps and tubes covering all WF Area. 
Statistical methods

Avian density (birds $/ \mathrm{km}^{2}$ ) according to distance of bird observation to the transect were calculated by DISTANCE 4.0 Beta 6 program (Thomas et al. 2002).

We used non-parametric statistics for those variables that were not normally distributed. We used the Wilcoxon Test to compare the IKA index of birds (birds $/ \mathrm{km}$ ) between areas. Kruskal-Wallis Test were used to compare the flight height between areas. When statistical differences appeared, post hoc comparisons were made with Mann-Whitney U-Test. Analysis of $v^{2}$ (goodness of fit) was used to analyse the predominated flight direction of birds between study area.

Kolmogorov-Smirnov Test was used to test normal distribution of bird's density. We used two ways ANOVA to analyse the density of birds through study periods and study areas.

Small-mammals are mainly caught one at each time in small traps. So, each capture can be recorded as an independent observation. Two forward stepwise logistic regression procedure were used to create the models of captures and signals, because this multivariate statistical technique permits the prediction of binary attributes such as presence/absence.

We used an alfa value of $\mathrm{p}=0.05$. SPSS 10.0 software statistical package was used to perform all statistical analyses.

Results

Composition, avian abundance and avian density

(1) Nesting birds

A total of 2121 birds from 21 different species in the two study areas in all study period (total observation $32 \mathrm{~h}$ ) were recorded. In 1995, 614 birds from 12 species were observed. In 1996, 833 birds from 16 species were observed. In 1997, 669 birds from 18 species were recorded (Table 1). Four species through study period were only detected in R Area: Fan-tailed Warbler, Cirl Bunting, Blackcap and Spectacled Warbler, and only one in WF Area: Greenfinch.

When comparing the IKA index of each species between study areas significant differences were observed only in 1996 (Table 2).

No significant differences were detected in IKA index between study periods neither in WF Area (Kruskal-Wallis Test, $\mathrm{X}^{2}=1.027$, df $=2, \mathrm{p}=0.599$ ), nor in R Area (Kruskal-Wallis Test, $\mathrm{X}^{2}=0.106, \mathrm{df}=2, \mathrm{p}=0.948$ ).

No significant differences in bird's density were detected between both study areas among study years (two-way ANOVA, $\mathrm{F}_{5,30}=0.794, \mathrm{p}=0.565$ ).

(2) No nesting birds

A total of 672 birds from 18 different species were recorded in the two study areas in the whole study period (total observation $32 \mathrm{~h}$ ) (Table 3). Five species were only detected in WF Area (Raven, House Martin, Yellowhammer, 
Swallow and Black Redstart) and Jackdaw, Nightingale and Pied Wagtail only in $\mathrm{R}$ Area.

When comparing the IKA index of each species between study areas no significant differences were detected (Table 4).

No significant differences in IKA index were detected between study years neither in WF Area (Kruskal-Wallis Test, $\mathrm{X}^{2}=0.187, \mathrm{df}=2, \mathrm{p}=0.911$ ) nor in $\mathrm{R}$ Area (Kruskal-Wallis Test, $\mathrm{X}^{2}=0.4296, \mathrm{df}=2, \mathrm{p}=0.808$ ).

Significant differences in bird's density were detected (two-way ANOVA, $\left.\mathrm{F}_{5,32}=3.501, \mathrm{p}=0.016\right)$ between both study areas $(\mathrm{F}=6.045, \mathrm{p}=0.022)$ among study years $(\mathrm{F}=3.779, \mathrm{p}=0.037)$. This variable showed higher values during 1995 in R Area.

Flight behaviour of birds

(1) Nesting birds

Only in 1996 significant differences were detected (WF Area rank $=376.74, \mathrm{R}$ Area rank $=457.36$; Mann-Whitney Test; $\mathrm{Z}=-5.576 ; \mathrm{n}=833 ; \mathrm{p}<0.0001$ ) when the height flight of birds between study areas were analysed. Nesting birds flew higher in R Area than in WF Area. Significant differences in flight height were detected between study periods in $\mathrm{R}$ Area (Kruskal-Wallis Test, $\left.\mathrm{X}^{2}=53.056, \mathrm{df}=2, \mathrm{p}<0.0001\right)$. Birds flew higher in $1996(\mathrm{rank}=591.53)$ than 1995 (rank $=477.94$; Mann-Whitney Test, $\mathrm{Z}=-5.831, \mathrm{p}<0.0001$ ) and 1997 (rank = 464.23; Mann-Whitney Test, $\mathrm{Z}=-6.253$, p < 0.0001). In WF Area flight height between study periods were not statistically different (KruskalWallis Test, $\mathrm{X}^{2}=5.426, \mathrm{df}=2, \mathrm{p}=0.066$ ).

(2) No nesting birds

Only in 1996 significant differences were detected when the flight height of birds between study areas were analysed (WF Area rank $=168.09$, $\mathrm{R}$ Area rank $=108.99$; Mann-Whitney Test, $\mathrm{Z}=-6.092, \mathrm{n}=257, \mathrm{p}<0.0001$ ). Nesting birds flew higher in WF Area than in R Area. Significant differences in flight height were detected between study periods in $\mathrm{R}$ Area (Kruskal-Wallis Test, $\left.\quad \mathrm{X}^{2}=13.809, \mathrm{df}=2, \mathrm{p}=0.001\right)$. Birds flew higher in 1995 $($ rank $=217.56)$ than 1996 (rank = 251.06; Mann-Whitney Test, $\mathrm{Z}=-2.642$,

Table 4. IKA index of no nesting species between study areas were analysed with Wilcoxon Test.

\begin{tabular}{lllllll}
\hline Years & Areas & Mean & SD & $\mathrm{n}$ & $\mathrm{Z}$ & $\mathrm{p}$ \\
\hline 1995 (pre) & WF & 0.239 & 0.310 & 18 & -1.025 & 0.305 \\
& R & 0.406 & 0.280 & & & \\
1996 (const) & WF & 0.552 & 0.285 & 20 & -1.022 & 0.307 \\
& R & 0.433 & 0.324 & & & \\
1997 (post) & WF & 0.334 & 0.265 & 32 & 0.000 & 1.000 \\
& R & 0.327 & 0.267 & & & \\
\hline
\end{tabular}


$\mathrm{p}=0.008)$ and than 1997 (rank $=190.50$; Mann-Whitney Test, $\mathrm{Z}=-1.901$, $\mathrm{p}=0.057$ ). Also in WF Area significant differences in flight height were detected between study periods (Kruskal-Wallis Test, $\mathrm{X}^{2}=64.036$, $\mathrm{df}=2$, $\mathrm{p}<0.0001)$. Birds flew higher in 1996 (rank=154.58) than 1995 (rank = 89.62; Mann-Whitney Test, $\mathrm{Z}=-6.584, \mathrm{p}<0.0001)$ and 1997 (rank = 76.91; Mann-Whitney Test, $\mathrm{Z}=-6.965, \mathrm{p}<0.0001$ ).

In 1995 (northern directions $=54$, eastern directions $=4$, southern directions $=14$ and western directions $=9$; expected ratio $25 \%$ in each direction; $\mathrm{X}^{2}=77.469$, df $=3, \mathrm{p}<0.0001$ ), and 1996 Northern flight direction predominated when flight direction were analysed in WF Area.

Statistical differences R Area in 1995 were detected. However in WF Area no predominated flight direction were detected $\left(\mathrm{X}^{2}=2.586, \mathrm{df}=3, \mathrm{p}=0.460\right)$ in 1995.

In 1996 in R Area predominated northern flight direction was detected (northern directions $=39$, eastern directions $=11$, southern directions $=13$ and western directions $=19$; expected ratio $25 \%$ in each direction; $\left.\mathrm{X}^{2}=23.951, \mathrm{df}=3, \mathrm{p}<0.0001\right)$, but not in WF Area $\left(\mathrm{X}^{2}=3.895, \mathrm{df}\right.$ $=3, \mathrm{p}=0.273$ ).

In 1997 predominated eastern flight direction were detected in $\mathrm{R}$ Area (northern directions $=12$, eastern directions $=18$, southern directions $=3$ and western directions $=7$; expected ratio $25 \%$ in each direction; $\mathrm{X}^{2}=12.6$, $\mathrm{df}=3, \mathrm{p}=0.006)$. In WF Area flight directions not were statistical differences $\left(\mathrm{X}^{2}=2.048, \mathrm{df}=3, \mathrm{p}=0.563\right)$.

\section{Small mammals}

Through the day, no small mammals were captured. In 1995, total capture effort was 897 traps-night and 936 tubes. Index of captures was 0.0025 small mammals per study day and number of traps-night $(n=13)$. All were Wood Mouse Apodemus sylvaticus and there were placed all in bushes. In middle vegetation cover $69.2 \%$ of total captures were situated, and in uniform landscapes the same percentage were found. About $53.85 \%$ of captures were situated in the second category of distance $(40-80 \mathrm{~m})$. The index of small mammal signs was 0.003 signs of small mammals per study day and number of tubes $(\mathrm{n}=18)$. About $38.9 \%$ of these were placed in grassland, $66.7 \%$ in open vegetation cover, $72.2 \%$ in edge landscape and $50 \%$ were in the second category of distance.

In 1996, total capture effort was 886 traps-night and 1842 tubes. Index of captures was 0.001 small mammals per study day and number of traps $(\mathrm{n}=7)$. All of these were identified as Wood Mouse Apodemus sylvaticus. The $57 \%$ of these were placed in rocks, the $57 \%$ were in middle vegetation cover, $71.4 \%$ were in edge landscape and $71.4 \%$ were in the second category of distance. The index of small mammal signs was 0.0005 signs of small mammals per study day and number of tubes $(\mathrm{n}=24)$. The $57 \%$ of these were placed in grassland, 
$71.4 \%$ were in dense vegetation cover, $71.4 \%$ were in edge landscape and $66.7 \%$ were in the third category of distance.

In 1997, total capture effort was 728 traps-night and 1442 tubes. Index of captures was 0.012 small mammals per study day and number of traps $(\mathrm{n}=59)$. One small mammals was Greater White-toothed Shrew Crocidura russula and the others were Wood Mouse Apodemus sylvaticus. About 51.2\% of these were in grassland, $44.2 \%$ were in middle vegetation cover, $51.2 \%$ were in edge landscape and $33.9 \%$ were in the second category of distance. The index of small mammals signs was 0.016 signs of small mammals per study day and number of tubes $(\mathrm{n}=118)$. The $49.5 \%$ of these were in bushes, $58 \%$ were in middle vegetation cover, $84.12 \%$ were in edge landscape and $38.13 \%$ were in the second category of distance.

The logistic regression model quantified the linear combination of independent variables best discriminating between presence/absence of captures in traps only study year variable entered the model $(\mathrm{B}=-0.191$, Wald $=6.1$, $\mathrm{df}=1, \mathrm{p}=0.014)$ and distance from turbines variable did not $(\mathrm{B}=-0.201$, Wald $=2.727, \mathrm{df}=1, \mathrm{p}=0.099$ ). Only study year entered into the logistic regression model in quantifying track signs in tubes $(\mathrm{B}=1.022$, Wald $=55.865, \mathrm{df}=1, \mathrm{p}<0.0001)$.This variable, in traps and tubes analysis, showed higher values in 1997.

\section{Discussion}

Windfarm installations did not clearly affect bird and small mammal populations, so the presence of turbines seemed not to be a significant problem for these populations. Avian abundance and avian density in breeding does not differ by study years (pre windfarm, windfarm installation and post windfarm) and between areas (R and WF). Avian density in no breeding birds show a light tendency to decrease with time. In contrast, Lucas et al. (2004) detected more abundance of passerines in a control area than the others (another control and windfarm areas). Leddy et al. (1999) supported the hypothesis of those areas without turbines support higher densities of grassland birds than areas near the turbines, and also Larsen and Madsen (2000) detected that wind farms caused a habitat loss equivalent to $4 \%$ of the total field area around the turbines for pink-footed geese (Anser brachyrhynchus).

Flight height of nesting and no nesting birds did not show a clear tendency. No nesting birds flew higher in 1996 in WF Area. This effect could be related to the machines and personal working in the construction of the windfarm. However, this effect did not appear in flight height of nesting birds. In Lucas et al. (2004) soaring birds we detected a significantly higher flight height in WF Area than in the others control areas.

Flight of nesting birds had not been considered because their flight were local distances and between bushes (Rodewald and Yahner 2001). In no nesting birds the predominated flight direction in $\mathrm{R}$ Area suggest that birds flew mainly 
in one direction (South-North), while in WF Area birds did not have a clear flight direction, changing often their direction of flight. Lucas et al. (2004) detected that $71.2 \%$ of soaring birds changed their flight direction when detecting the turbines on the top of the mountain, and Dirksen et al. (1998) also showed that birds changed their flight direction more often when the turbines were operating than when they were not. So turbine lines might act as flight path barriers.

Small-mammals populations suffered high variations in numbers through times by several factors (Snyder 1978). The higher index of captures and signs in 1997 could be assumed to (1) several factors affecting populations, (2) change in vegetation variables with the construction of windfarm (open landscape, less bushes) and (3) umbrella effects of small-mammals predators (Chase et al. 2000).

There was a spatial distribution on small-mammals captures. The strip of distance more used were $40-80 \mathrm{~m}$ in all study years. Because an increase of captures near turbines is expected through study years, the second hypothesis can not supported. The impact of the construction of turbines specially could be only in the immediate vicinity of the wind park. This contradicts findings of Guillemette and Larsen (2002) that the wind park did not influence the distribution of eiders because their experiments conducted at a small spatial scale (around the wind park) showed that wind turbines did not have a negative influence on the distribution and the abundance of small-flock common eiders when correcting food availability. The third hypothesis has not been out but avian community have not changed through study years.

In conclusion, our results do not support an important effect of the windfarm on birds and small-mammals populations. The BACI design we had used was criticised by Hurlbert (1984) on the basis that the control site would need to be very similar to the impact site in order to come up with a sound conclusion. Therefore our study areas (Reference and Windfarm) were chosen to be very similar in characteristic of landscape, vegetation and altitude.

\section{Management applications}

Our study may have important implications for the future development of wind farms. Bird and small-mammals populations might not affected by the presence of turbines. Soaring birds detected the turbines and change their flight direction and small-mammals seems not to be affected by the new constructed windfarm. These results could not be extrapolated to another areas with different avian community and sampling in the long run can be suggested.

Attention to the intricate relationship that may exist between the presence/ absence of disturbance and the probability of collisions with turbines. Therefore, absence of disturbance may increase the probability of collisions (Guillemette and Larsen 2002). We did not study mortality because in the After 
period the windfarm had been operating as full potential only for a few months.

There are many practical problems of detection of human influence on abundances of populations, but two are paramount in designing sampling programs. First is the large temporal variance of many populations, so that their abundances are very 'noisy'. Second, many populations show a marked lack of concordance in their temporal trajectories from one place to another. This results in considerable statistical interaction between changes in mean abundance from time to time and differences from place to place (Underwood 1994).

Any difference in abundance between the impact and the control sites could be explained by a priori differences in the two sites and that no causal relationship of presence/absence of an impact could be derived from this design (Hurlbert 1984). So post-development experiences should be considered a complement to BACI studies rather than an alternative (Guillemette and Larsen 2002).

\section{Acknowledgements}

We thank all the people who took part in the field work, in particular R. Roozen, J.L. Arroyo, N. Selva and A. Garcia. J. Sanchez and A. Lazo from Asistencias Tecnicas CLAVE S.L. helped us with the technical report. Dr Vincenzo Penteriani, Dr Jordi Figuerola, Dr Ramon Soriguer and Roger Jovani helped us with their comments that improved the manuscript. The field study was supported by Ecotecnia S. Coop. and by a fellowship grant from a group of seven Spanish wind developers (ENDESA, Cogeneracion y Renovables S.A., Aerogeneradores del Sur S.A., Microcentrales de Andalucia S.A., WIGEP Andalucia S.A., Wind Iberica Espana S.A., PEESA, Alabe la Ahumada S.L.) and from Estacion Biologica de Donana (Consejo Superior de Investigaciones Cientıficas). Manuela de Lucas would like to extend special thanks to F. Romero, for whose help and support she is indebted.

\section{References}

Alonso C. 2002. Parque Natural de las Islas Atlanticas de Galicia. La fuerza del mar. Ambienta (http://hispagua.cedex.es).

Anderson R., Morrison M., Sinclair K. and Strickland D. 1999. Studying Wind Energy/Bird Interactions: A Guidance Document. National Wind Coordinating Committee (NWCC), Washington.

Blanco J.C. and Gonzalez J.L. 1992. Libro Rojo de los Vertebrados de Espana. Coleccion Tecnica ICONA, Madrid.

Chase M.K., Kristan W.B. III, Lynam A.J., Price M.V. and Rotenberry J.T. 2000. Single species as indicators of species richness and composition in California coastal sage scrub birds and small mammals. Conserv. Biol. 14: 474-487.

Dirksen S., Winden J.v.d. and Spaans A.L. 1998. Nocturnal collision risks of birds with wind turbines in tidal and semi-offshore areas. Wind Energy Landscape 99-107. 
Erickson W.P., Johnson G.D., Strickland M.D., Young D.P., Sernka K.J. and Good R.E. 2001. Avian Collisions with Wind Turbines: A Summary of Existing Studies and Comparisons to Other Sources of Avian Collision Mortality in the United States. National Wind Coordinating Committee (NWCC) Resource Document.

Ferry C. and Frochot B. 1958. Une methode pour denombrer les oiseaux nicheurs. Terra e Vie 105(2): 85-102.

Green R.H. 1979. Sampling Design and Statistical Methods for Environmental Biologist. John Wiley and Sons, New York.

Guillemette M. and Larsen J.K. 2002. Postdevelopment experiments to detect anthropogenic disturbance: the case of Sea Ducks and Wind Park. Ecol. Appl. 12(3): 868-877.

Guillemette M., Larsen J.K. and Clausager I. 1998. Impact Assessment of an Off-shore Wind Park on Sea Ducks. National Environmental Research Institute, Report number 227.

Hurlbert S.H. 1984. Pseudoreplication and the design of ecological field experiments. Ecol. Monogr. 54(2): 187-211.

Howell J.A. 1997. Avian Use and Mortality at the Sacramento Municipal Utility District Wind Energy Development Site, Montezuma Hills, Solano County, California. Sacramento Municipal Utility District, California.

Larsen J.K. and Madsen J. 2000. Effects of wind turbines and other physical elements on field utilization by pink-footed geese (Anser brachyrhynchus): a landscape perspective. Landscape Ecol. 15: 755-764.

Leddy K.L., Higgins K.F. and Naugle D.E. 1999. Effects of wind turbine on upland nesting birds in conservation reserve program grasslands. Wilson Bull. 111(1): 100-104.

Lucas M.d., Janss G. and Ferrer M. 2004. The effects of a wind farm on birds in a migration point: the Strait of Gibraltar. Biodiv. Conserv. 13: 395-407.

Morrison M.L. and Sinclair K. 1998. Avian Risk and Fatality Protocol. National Renewable Energy Laboratory (NREL), Colorado.

Musters C.J.M., Noordervliet M.A.W. and Terkeus W.J. 1996. Bird casualties caused by a wind energy project in an estuary. Bird Study 43: 124-126.

Natural S.G.d.H. 1995a. Atlas de Vertebrados de Galicia. Tomo II: Aves. Santiago de Compostela.

Natural S.G.d.H. 1995b. Atlas de Vertebrados Terrestres de Galicia. Tomo I: Peixes, Anfibios, Reptiles e Mamiferos. Santiago de Compostela.

Nelson H.K. and Curry R.C. 1995. Assessing avian interactions with windplant development and operation. Trans. 60th No. Am. Wildl. \& Natur. Resour. Conf. 266-277.

Orloff S. and Flannery A. 1992. Wind Turbine Effects on Avian Activity, Habitat Use, and Mortality in Altamont Pass and Solano County Wind Resource Areas. California Energy Commission (CEC), California.

Orrock J.L., Pagels J.F., McShea W.J. and Harper E.K. 2000. Predicting presence and abundance of a small mammal species: the effect of scale and resolution. Ecol. Appl. 10(5): 13561366.

Osborn R.G., Higgins K.F., Usgaard R.E., Dieter C.D. and Neiger R.D. 2000. Bird mortality associated with wind turbines at the buffalo ridge wind resource area, Minnesota. Am. Midland Nat. 143: 41-52.

Page D.S., Gilfillan E.S., Boehm P.D. and Harner E.J. 1993. Shoreline ecology program for Prince William Sound, Alaska, flowing the Exxon Valdez oil spill: Part 1- Study design and methods. DRAFT. Third Symposium on Environmental Toxicology and Risk: Aquatic Plant, and Terrestrial. American Society for Testing and Materials. Philadelphia, PA.

Rivas-Martınez S. 1987. La vegetacion de Espana. Universidad Alcala, Madrid.

Rodewald A.D. and Yahner R.H. 2001. Influence of landscape composition on avian community structure and associated mechanisms. Ecology 82(12): 3493-3504.

Snyder D.P. 1978. Populations of small mammals under natural condition. The University, Pittsburgh. 237 pp.

Stekoll M.S., Deyster L., Highsmith R.C., Saupe S.M., Guo Z., Erickson W.P., McDonald L. and Strickland D. 1993. Coastal Habitat Injury Assessment: Intertidal communities and the Exxon 
Valdez oil spill. Presented at the Exxon Valdez Oil Spill Symposium, February 2-5, 1993. Anchorage, Alaska.

Stewart-Oaten A. 1986. The Before-After/Control-Impact-Pairs Design for Environmental Impact Assessment. Marine Review Committee, California.

Strickland D., Johnson G.D., Erickson W.P., Sarappo S.A. and Halet R.M. 1998. Avian Use, Flight Behavior, and Mortality on the Buffalo Ridge, Minnesota, Wind Resource Area. National Avian - Wind Power Planning Meeting III, San Diego, California.

Telleria J.L. 1986. Manual para el Censo de los Vertebrados Terrestres. Madrid.

Thelander C.G. and Rugge L. 1998. Bird Risk Behaviors and Fatalities at the Altamont Wind Resource Area. National Avian - Wind Power Planning Meeting III. San Diego, California.

Thomas L., Laake J.L., Strindberg S., Marques F.F.C., Bochers D.L., Buckland S.T., Anderson D.R., Burham K.P., Hedley S.L. and Pollard J.H. 2002. Distance 4.0 Beta 6. Research Unit for Wildlife Population Assessment University of St. Andrews, UK. (http://www.ruwpa. stand.ac.uk/distance).

Underwood A.J. 1994. On beyond BACI: sampling designs that might reliably detect environmental disturbances. Ecol. Appl. 4(1): 3-15.

Winkelman J.E. 1990. Bird collision victims in the experimental wind park near Oosterbierum (Fr), during building and partly operative situations (1986-1989). Instituut voor Bos- en Natuuronderzoek, Wageningen. 